\title{
Developing the Moral Integrity of College Sport through Commercialism
}

\author{
Robert C. Schneider
}

The College at Brockport, State University of New York, USA

ABSTRACT

Despite criticisms that commercialism corrupts college sports (Duderstadt, 2003, Roberts 2008, Zimbalist 2006), commercialism, if executed appropriately can strengthen and develop the moral integrity of sport. A utilitarian approach to the commercialization of sport can be used to strengthen its moral integrity. From a utilitarian standpoint, John Stuart Mill's greatest happiness principle and Jeremy Bentham's hedonic calculus can be used to help determine specific approaches to the commercialization of sport. The interests of the sporting community including sport participants, coaches, administrators, fans, and community members, must be considered when commercializing sport to a moral end. Thoroughly understanding a morally grounded mission in a sport organization is a prerequisite to the effective negotiation of terms of commercial agreements that mutually support the mission of the commercial entity and sport organization. The commercialization of sport includes but is not limited to television contracts, venue signage, licensing of merchandise, and corporate sponsorships. Identifying a professional "fit" between the sport organization and commercial entity is imperative. The use of common sense, and experience as outlined by Mill and Bentham (as cited in Beauchamp 1982) and understanding human nature as outlined by Hume $(1739 / 1964)$ are useful when attempting to determine how particular commercialism efforts may consciously or subconsciously develop or reduce the moral integrity of sport. Beyond sport, the influences and risks of commercialism can be understood by observing its effect on non-sport organizations. Threats to the moral integrity of sport arise when entering into revenue generating commercial agreements. Sport's overreliance on revenue from a commercial entity is a factor that can potentially cause deviation from a sport organization's morally based mission. Excessive expansion and lavish funding of sport organizations can contribute to overreliance on revenue from commercial entities. Personal greed can also play a role in detracting from the moral integrity of the mission.

KEYWORDS

virtue, here and now, sentiments

\section{Enjoyment experienced by college sport}

This November, as an alumnus of the Ohio State University (OSU), the author of this paper will attend what has been referred to as the biggest rivalry in American college sports, the Ohio State versus Michigan football (American) game. The game will take place under a highly commercialized atmosphere. It will be televised as part of a network contract generating tremendous amounts of revenue for the National Collegiate Athletic Association (NCAA), Big 10 Conference, and both universities. Apparel will be sold for profits. Gate receipts of several millions of dollars will be generated, not to mention the many corporate deals, and additional commercial activity that have been 
negotiated - all in the interest of revenue generation. The entire weekend will include festivities, alumni gatherings, and tailgating enjoyed by all involved. During the game, over 100,000 fans will fill Ohio Stadium in support of their Buckeyes. What is wrong with a model that brings together and provides enjoyment to over 100,000 community members, students, alumni, and visiting fans at a sporting event on a Saturday afternoon?

\section{College sport commercialism and its growth}

It is doubtful that acts to increase the commercialization and subsequent growth of college sport are taking place for moral reasons but nevertheless growth is occurring. The more likely reason for the increased commercialization of college sport is for the generation of more revenue. In general, commercialism is defined as the practices, methods, aims, and spirit of commerce or business; an attitude that emphasizes tangible profit or success; and an excessive emphasis on profit (Commercialism, n.d.). Hirsch (1976) described the commercialization effect as the characteristic of an activity that supplies that activity exclusively on commercial terms rather than some other obligation.

Commercialized sport enters into public spaces through several outlets including program advertisements, electronic message board endorsements, public address system announcements, camera visible signage in the form of billboards, website banners, goalpost pads, basketball bench chair backs, hockey dasher boards, and back-lit concourse signs (King \& Slaughter 2004). Athletic departments depend on a combination of gate receipts, concessions, and sponsorships (Coakley 2004). Stadium rights are also driven by commercialism (Malec 2007).

On its largest scale, commercialized sport is organized and played to make money as entertainment events and is intimately tied to revenues generated by television broadcasting rights (Malec 2007). The growth of the commercialization of college sport was exemplified in April of 2010 when the NCAA announced their agreement to a $\$ 10.8$ billion contract with Columbia Broadcasting System (CBS) Sports and Turner Broadcasting beginning in 2011 through 2024 (NCAA 2010a). The NCAA posts 11 major corporate partners on its website (NCAA 2010b) and more and more of its member institutions have taken on or have increased their commercialization efforts. From a league standpoint and most recently, the Big 10 conference, which actually consists of 11 teams because of the addition of Penn State several years ago, made a decision to add Nebraska, making for 12 teams. This growth and commercialism is driven by money.

\section{Commercialization of college sport and utilitarianism}

From a utilitarian standard, happiness and unhappiness resulting from college sport influenced by commercialism can be used to help determine its moral standing. John Stuart Mill's greatest happiness principle serves as a moral guide: "actions are right in proportion as they tend to promote happiness, wrong as they tend to produce the reverse of happiness" (Mill 1863/1969, p. 36). Then, in the simplest utilitarian sense, commercially driven actions by those affiliated with college sport are right if they produce happiness and wrong if they produce unhappiness. A cursory review might consider the extent to which the day-to-day activities of college sport result in happiness or unhappiness to those directly affiliated with college sport. At a quick glance, aside from commercialism's goal to generate revenue, the sentiments of the college sporting community seem to be highly pleasurable and are easily identifiable. Pain, however, is also experienced by those close to college sport.

The degree, to which college sport is shaped by commercial influences and produces happiness and unhappiness, helps determine its moral standing as it exists under those commercial influences. If commercialism is a primary influencer of the college sport product and if college sport provides more 
happiness than unhappiness, the influence of commercialism can be considered something that enhances the morality of college sport, at least from a utilitarian perspective.

Happiness from a utilitarian stand point is meant to go beyond the temporary feelings of elation that comes with a player winning a game or a coach signing a recruit. This de-emphasis of minute feelings also holds true when measuring unhappiness. The temporary physical pain from a rigorous practice or emotional loss of a game is not heavily weighted when attempting to determine the overall moral standing of college sport.

\section{A here and now approach}

Attempts to gage morality through a "here and now approach" is an adequate starting point when endeavoring to factor in all of the short- and long-term aspects, of a commercially influenced college sport, that bring about happiness and unhappiness. Not helpful, however, when attempting to determine the overall moral standing of college sport is the selective identification of causes of happiness or unhappiness. An overall or holistic approach should be used.

From a utilitarian standpoint the argument can be made that the commercialization of college sport should remain because it provides a greater amount of pleasure than pain to the sporting community. The sporting community might be described as players, friends and families of players, coaches, fans, and athletic directors who are directly related to college sport. Happiness scores well on utilitarian Jeremy Bentham's hedonic calculus circumstance of intensity and fecundity because happy sentiments of the sporting community can be both powerful and contagious. The power of winning can spread through the sporting community and beyond, into cities, states, and even countries. If direct gains of pleasure go beyond winning, Bentham's "duration" circumstance is likely extended.

Positive sentiments resulting from college sport and experienced by members of the sporting community are many. Players learn how to compete and cooperate. Skills are acquired and developed through self-discipline and a work ethic. Lifelong friendships are made. Coaches earn an income as they immerse themselves in an occupation that stimulates their passion. They gain pleasure from overcoming the challenges required to create a flawlessly executing team. Despite the sometimes tumultuous existence of coaching, very few coaches express long-term regrets. Fans of college sport look forward to attending the games. University campuses on game day are abuzz with excitement. Students, alumni, and fans from near and far come together to enjoy watching the game. Athletic department employees, including athletic directors contribute to this process that produces the positive outcomes resulting from college sport.

\section{Happiness from increased commercialism of college sport}

If the athletic experience from college sport organizations brings about good for its athletes and the sporting community in general, the growth of college sport through commercialism could increase the good. Money generated through commercialism would allow for additional resources and subsequent increases in teams and participants, who would experience the same good. Increasing commercialism to merely remain financially solvent is not uncommon (Brent \& Lunden 2009, Malec 2007, Shaw 2000) but is not moral in and of itself; however, if a byproduct is happiness for more members of the sporting community, continued commercialization of college sport can be considered morally good.

Despite the prevalence of commercialism in college sport, former NCAA executive director Myles Brand, advocated for more commercialism in his 2009 NCAA state of the Association speech (Brand 2009). He pointed out that benefits include higher application rates for the general student body, as well as campus morale and community building (Brand 2009). An NCAA presidential task force in 2006 claimed that increased corporate sponsorship opportunities including the sale of broadcast rights, logo licensing, and other fundraising ventures provide significant revenue to support 
college athletics and increases the quality of the student-athlete experience (NCAA Presidential Task Force 2006).

A serious challenge, though, could be in predicting the extent to which an increase in the commercialization of college sport might tip the sporting community's sentiment scale toward unhappiness. Using Bentham's (1789/1961) hedonic calculus as a guide, the agent is to, "sum up all the values of all the pleasures on the one side, and those of all the pains on the other" (p. 39). If the summation is on the side of pleasure the act will tend to be good and if on the side of pain, tend to be bad. As long as the holistic summation of the happiness is greater than the unhappiness, college sport can be considered morally good; however, when unhappiness is greater, college sport has moved in the direction of immorality.

\section{Revenue generation at the expense of the integrity of college sport}

Thus far the focus of this paper has primarily been on the happiness resulting from the commercialism of college sport, which is supportive of moral good. Commercialism, however, also clashes with moral good. Commercialism's emphasis on revenue generation often lies at odds with the integrity of sport. As college sport moves toward extreme commercialism, its integrity becomes more at risk. With the opportunity to generate revenue before their eyes, many NCAA schools find the temptations of success too alluring to worry about the rules (Zimbalist 1999). The NCAA, according to Kessler (2004), has clearly lost its way because of their pursuit of billion dollar profits.

The NCAA Presidential Task Force in 2006 stated that the need for increasing the rate at which revenue is generated can result in an inflated need to increase wins, which may stimulate unethical recruiting practices (NCAA Presidential Task Force 2006). Unethical practices also take place by illegally paying recruits, illegally helping prospective athletes pass standardized tests, and maintaining athlete eligibility through inferior academic curricula (Zimbalist 1999), all for the purpose of increased revenue.

\section{Commercialism's inconsistency with the educational mission}

Commercial activity can go too far and in doing so can subvert the values and mission of higher education (Brand 2009). Zimbalist (2006) spoke of inconsistencies with the educationally NCAA based mission and the commercialized activities of the NCAA. The NCAA Presidential Task Force (2006) pointed out that in college athletics, the focus should be on the individual athlete, as a student first.

College athletics must serve the institutional mission and answer to the traditional standards of higher education instead of operating as a freestanding, enterprise driven by the whims and pressures of the marketplace (NCAA Presidential Task Force 2006). Currently, college athletics is separating itself from academic institutions in a variety of ways including but not limited to: coaches salaries, unregulated sponsorships contracts, competition for corporate dollars, market exposure vocabulary, centering the college experience on sports, and not enforcing graduation guidelines for athletes (Malec 2007). It should be noted, that college sport is not alone in its commercial endeavors, as universities, overall, have also increased commercialism efforts.

\section{Over-commercialization of college sport}

If commercialism includes, as stated by Twitchell (1999), the stripping of an object of all other values except its value for sale to someone else, it should come as no surprise when organizations which rely exclusively on commercialism for funding, become morally defunct. When values begin to lose their hold, the urge to make money quickly spreads (Bok 2003) and the gain of money and material possessions never ends up being enough to satisfy desires (Bok 2003, Herman 1999). 
When college sport is treated as a commodity, generating revenue through product sales is primary and can crowd out morality. Much of the extraordinary value of college sport depends on its integrity, which is lost when commercial interests overwhelm the game (NCAA Presidential Task Force 2006). Over-commercialization, which transposes the collegiate model into a system that more closely resembles the professional model and threatens the integrity of college sports, must be avoided (NCAA Presidential Task Force 2006). When money becomes the chief or only goal and values are squeezed because attention to them hampers the accumulation of money, then money has triumphed as the single end (Engell \& Dangerfield 2005).

Excessive luxuries that result from commercialism ultimately expose a decline in virtues (Pocock 1975). The importance of controlling the growth of luxury, i.e., the generation of revenue that comes with winning in college sport, is further reinforced by Bok (2003) who claimed that the insistence of winning by boosters, alumni supporters, and legislators might be the greatest obstacles to reforming college sport from commercialism. The yearning for luxuries associated with winning in college sport is recognized by Duderstadt (2003) who pointed out that the public and governing boards' demand for high quality entertainment from their sports teams is often enough to fire presidents who do not share the same enthusiasm.

If the emphasis on making money, in fact, is exclusive, the commercialization of college sport runs the risk of drowning out other goals, not the least of which includes morally good behavior. The NCAA must guard against exclusive commercialism if they wish to maintain the integrity of their product. In a commercialized athletic department, difficulty is encountered when attempting to adhere to morals because as stated by Shuker (2003) commercialism is driven by the consumer market economy.

The consumer market economy does not proactively address morals. On the contrary, it is based on the generation of revenue, which could further weaken the integrity of college sport. Thus, as college sport becomes more and more commercialized, the focus of emphasis is less centered on education and morals unless per chance the sporting communities' purchasing tendencies require that the sport product be morally focused.

\section{Incompatibility of the commercialization of college sport and morals}

The overall literature, not necessarily related to sport, is supportive of Alvey's (2003) claim that as commercialism takes hold virtue declines. Several sources also point out that as money and material possessions grow, virtue and morality seep away (Greenberg 2007, Herman 1999, Rasmussen \& Uyl 1991). Persons who are part of an environment of commercialism are more likely to act without conscience when attempting to satisfy their interests (Manzer 1996). Acting without good conscience jeopardizes morality from a utilitarian standpoint, as Mill (1863/1957) pointed out that a good conscience is required to effectively apply utilitarianism.

Parallels can be made between the commercialization of college sport and the slippage of morals that appear to follow. Over the years, money and material possessions associated with college sport have grown, which does not bode well for a strong moral base in college sport.

Roberts (2008) pointed out that major university football and basketball are based on a set of values that, while perhaps appropriate for show business, are highly corrupt. Football continues to use commercialism to increase revenue with longer schedules allowing for more televised games, and there are ongoing discussions to develop a format for a national championship tournament. Men's basketball recently increased their post-season tournament field from 65 to 68 , which will generate additional revenue through commercial broadcasts. Presidents, athletic directors, coaches, and other members of the sporting community who, in fact, are part of an environment of commercialism, then, might be more likely to act without conscience when attempting to satisfy their interests. 


\section{The whiskey argument analogy}

Reality is shaped by public sentiment and often conflicts with idealism. As such, completely banning commercialism from college sport would be ideal in terms of maintaining the integrity and an educationally based mission of college sport. However, a complete ban on the commercialization of college sport is unrealistic because the sporting community does not support a complete ban. The split sentiments held by the sporting community with regards to the appropriateness of commercialism in college sport would make the banning of commercialism difficult to enforce. Sentiment of the sporting community for commercialism appears to be at least as strong as the sentiment against it. The overall desires of the sporting community support many of the luxuries extended by commercialism.

When arguments for and against an issue are divided among the affected community, extreme legislation is unenforceable and does not have staying power. Past legislation prohibiting alcohol in American states serves as an example of ineffective law because of the strong sentiment among members of society against it. Through the use of lighthearted humor, in his Whiskey Speech of 1952, legislator Noah Sweat outlined arguments for and against the legalization of alcohol in his state of Mississippi (Sweat 2007). On one hand Sweat spoke against whiskey by referring to it as the devil's brew, the poison scourge, and bloody monster that defiles innocence. He then argued for the legalization of whiskey stating that it is the drink that pours into our treasuries untold millions of dollars which are used to build highways, hospitals, and schools, and to care for persons in need.

Similar to considering the sentiments of society when legislating for the regulation of alcohol, the sentiments of the sporting community must be considered when regulating the commercialization of college sport. For without the support of the sporting community, enforcement will be ineffective in a way similar to which the enforcement of prohibition was ineffective due to the lack of societal support. Much in the same way society did not accept and conform to prohibition legislation it is doubtful that the sporting community would accept or conform to an all out ban on the commercialization of college athletics. In fact the sporting community appears to support increases in commercialism, i.e., expansions previously discussed.

A complete ban on the commercialization of college sports would drastically change college sport as the sporting community has come to know it. An outcry from the sporting community would likely result. The overall good that can result from the commercialization of sport must be weighed against the potential damage it will do to college sport, which, again, is measured by the sentiments of those affected by college sport, including the sporting community.

\section{Aristotle's golden mean - a happy medium}

When discussing commercialism's place in the NCAA, Myles Brand used Aristotle's doctrine of the Golden Mean to drive home the point that the benefits gained from the commercialization of the NCAA are not worth giving up in the interest of the achievement of pure idealism (Brand 2009). In Nicomachean Ethics, Aristotle (1941, p. 963) stated that "moral virtue is a mean, then, and in what sense it is so, and that it is a mean between two vices, the one involving excess, the other deficiency...". In the case of college sport, excess is represented by crass commercialism at one end and pure idealism at another; thus, both are considered vices. Somewhere approaching the extremes is an intermediate position that is considered virtuous. Aristotle pointed out that the perfect mean is not usually found in the arithmetic middle but rather is relative to particular circumstances (Aristotle 1941).

To actually find the perfect mean requires the sporting community to come to terms with an understanding of the "perfect" point on the continuum leading up to crass commercialism and pure idealism. Knowing the reality of each extreme is necessary prior to being able to identify a perfect mean. Extremes of commercialism include at one end, sport that is completely driven by commercialism and at the other end sport that is void of all commercialism. College sport dominated 
by commercialism would operate under the influences of the commercial entities funding it; whereas college sport void of commercialism would be free to operate in a manner of its choosing without influence from commercial entities but only if from a financial standpoint it could afford to operate. At some point, presumably, operating at either extreme of the commercialism continuum could result first in morally corrupting sport and ultimately in the demise of college sport as it is currently known. The extent of unhappiness among members off the sporting community determines the degree to which college sport is immoral and subsequently susceptible to collapse.

Finding the perfect mean or balance of commercialism is necessary to achieve virtue in college athletics. In reality, a perfect mean may not be achievable but a utilitarian mean —one that satisfies the most persons in the sporting community - is one that can provide a framework from which to base the amount of commercialism in college sport necessary for it to be considered moral.

\section{Achieving the golden mean through a utilitarian approach}

Regardless of attempts to manage markets and consumerism, markets simply are not able to be controlled completely, especially in a system of free enterprise and capitalism. The will of the consumer is a strong force that influences markets. When Bok (2003) referred to boosters, alumni supporters, and legislators as the greatest obstacle to reforming college athletics he was referring to members of the sporting community whose primary goal is to win and who will impose their will to that end. They will not be satisfied unless winning is achieved. When attempting to achieve the Golden Mean, understanding the will of the consumer, in the pursuit of happiness, is to also recognize the need to reach a balance between traditional university ideals and the commercialization of college sport.

Duderstadt (2003) spoke of the difficulties presidents face if they do not acknowledge the publics' demand for high quality entertainment from the commercial college sports' industry. Equally difficult for presidents, is to maintain traditional university ideals by holding sports programs to standards that reinforce those ideals. In the interest of morality, a balance must be reached between the commercialization of sport and traditional ideals, to prevent conflict that often seems to occur between the two. For example, the commercialization of college sports may conflict with traditional ideals related to academic standards and the recruiting of athletes. It may be difficult to recruit the athletes capable of generating money for a university and who also meet traditional academic standards expected of all students enrolled at the university. Commercialism and its interest in generating money from college sport, currently do not fully support traditional university ideals.

\section{Predicting happiness from increased commercialism}

The discussion thus far must only be considered a surface conversation because it does not provide insights into the potential long-term moral effects of increasing the commercialization of college sport. As stated previously, if the moral status of college sport is somewhat sound, the real challenge then could be in predicting the extent to which an increase in the commercialization of college sport might drive it in the direction of morality. Predictions must be made that determine the extent to which an increase in commercialism will promote more happiness or the most happiness as opposed to the reverse of happiness.

Using Bentham's hedonic calculus as a guide, regarding increasing commercialism, when the holistic summation of the pains felt by the sporting community is more than the summation of the pleasures, college sport is more immoral than moral. However, a utilitarian approach to morality must consider not only the sentiments of the sporting community but also the university community, and beyond. The university community and society in general should also be included when weighing the happiness and unhappiness caused by college sport. If using Jeremy Bentham's hedonic calculus, not only must all pleasures and pains be measured but the intensity (as well as additional circumstances) 
of pains and pleasures must also be taken into account. In other words particular members of the sporting community or university community might place more emphasis on a specific circumstance such as the intensity of a sentiment as opposed to the overall number of sentiments resulting from outcomes of various commercialism activities affecting college sport. Particular segments of members of the university community, i.e., members of the faculty senate, might be more intense or carry more weight than others. The intensity of pain or pleasure felt and distributed by a president of a university throughout a university might be of a higher magnitude than that of the sporting community. On some occasions the intensity of pleasure or pain of a few individuals might spread to others, increasing the total sum of sentiments that Bentham requires be calculated.

Moreover, the overwhelming sentiment of students and alumni from the sporting community might hold stronger sentiments than a president of a university. In the early 1900s more than a few university presidents protested the growth of football programs, only to be overcome by the tidal force of enthusiastic students and alumni (Bok 2003). If the collective will of those who support college sport - presumably because it makes them feel good - is stronger than those who do not, sport stands a good chance of flourishing with increased commercialism.

\section{Final thoughts}

When universities rely on revenue from outside sources, the organization's product runs the risk of being changed by the wants of the outside financiers. Directors of the NCAA must keep close eye on the market to ensure the ability to maintain a semblance of morals in the form of the maintenance of overall happiness, for if and when the NCAA is dependent on sponsors for its existence, morals will be further jeopardized because the NCAA will not be in a position to decline lucrative financial offers from companies, whose influences could generate unhappiness.

Higher education, according to Brand (2009), has understood the necessity of balancing commercialism with university ideals for over one hundred years. Care, however, must be taken to ensure that the scale does not tip in favour of commercialism at the expense of morals within college sport. For if commercialism gains too much momentum it could reach the extreme Aristotle warned against, which would also make for a less than satisfied sporting community, moving college sport down a path of immorality that could, under the worst case scenario lead to its demise.

\section{REFERENCES}

Alvey, J. E. (2003). Adam Smith's view of history: consistent or paradoxical? History of the Human Sciences, $16(2), 1-25$.

Aristotle (1941). Nicomachean ethics, Book II (W.D. Ross, Trans.). In R. McKeon (Ed.) The basic works of Aristotle (pp. 927-1112). New York: Random House.

Beauchamp, T. L. (1982). Mill and utilitarian theories (pp. 71-106). In T.L. Beauchamp, Philosophical ethics: An introduction to moral philosophy. New York: McGraw-Hill.

Bentham, J. (1789/1961). An introduction to the principles of morals and legislation. In Utilitarianism (pp. 7398). Garden City, NY: Doubleday.

Bok, D. C. (2003). Universities in the marketplace: the commercialization of higher education. Princeton, NJ: Princeton University Press.

Brand, M. (2009, January). 2009 NCAA state of the Association. 2009 NCAA State of the Association Speech delivered by Wallace I. Renfro at the 103rd NCAA Annual Convention, Washington, D.C. Speech retrieved from http://www.ncaa.org/wps/wcm/connect/public/ncaa/about+the+ncaa/who+we+are/myles+brand+legacy/ legacy+of+leadership/2009+ncaa+state+of+the+association.

Brent, B. O., Lunden. S. (2009). Much ado about very little: the benefits and costs of school-based commercial activities. Leadership and Policy in Schools, 8(3), 307-336. DOI: 10.1080/15700760802488619.

Coakley, J. J. (2004). Sports in society: issues and controversies. New York, NY: The McGraw-Hill Companies, Inc. Commercialism. (n.d.). In Merriam-Webster's online dictionary (11th ed.) Retrieved from http://www.merriam-webster.com/dictionary/commercialism. 
Duderstadt, J. J. (2003, October). Reforming college sports. Paper presented at the National Symposium, Tulane University, New Orleans, LA.

Engell, J., Dangerfield, A. (2005). Saving higher education in the age of money. Charlottesville, VA: University of Virginia Press.

Greenberg, D. S. (2007). Science for sale: the perils, rewards, and delusions of campus capitalism. Chicago, IL: The University of Chicago Press.

Herman, A. (1999). The "better angels" of capitalism: rhetoric, narrative, and moral identity among men of the American upper class. Boulder, CO: Westview Press.

Hirsch, F. (1976). Social limits to growth. Cambridge, MA: Harvard University Press.

Hume, D. (1739/1964). A Treatise of Human Nature. (L.A. Selby-Bigge, Ed.). Oxford: Clarendon Press. (Original work published in 1739).

Kessler, J. L. (2004, March 28). Tournament has become March monopoly madness. The New York Times. Retrieved from http:/www.nytimes.com/2004/03/28/sports/ncaabasketball/28KESS.html.

King, S., Slaughter, S. (2004). Sports 'R' us: contracts, trademarks, and logos. In S. Slaughter \& G. Rhoades (Eds.) Academic capitalism and the new economy: markets, state, and higher education (pp. 256-278). Baltimore, MD: The Johns Hopkins University Press.

Malec, M. (2007). College sports. In C. Gilde (Ed.) Higher education: open for business (pp. 107-124). Lanham, MD: Lexington Books.

Manzer, R. A. (1996, November). The promise of peace? Hume and Smith on the effects of commerce on war and peace. Hume Studies, XXII(2), 269-382.

Mill, J. S. (1863/1957). Utilitarianism. (O. Piest, Ed.). Indianapolis: Bobbs-Merrill. (Original work published in 1863).

Mill, J. S. (1863/1969). Utilitarianism. In J. M. Smith \& E. Sosa (Eds.) Mill's Utilitarianism (pp. 31-88). Belmont, CA: Wadsworth.

NCAA (2010a). CBS Sports, Turner Broadcasting, NCAA reach 14-year agreement Retrieved from: http://www.ncaa.com/sports/m-baskbl/spec-rel/042210aaa.html.

NCAA (2010b). NCAA corporate champions and corporate partners (2010). Retrieved from: http://www.ncaa.org/wps/portal/ncaahome?WCM_GLOBAL_CONTEXT=/corp_relations/corprel/corporate+rel ationships/corporate+alliances/partners.html.

NCAA presidential task force on the future of Division I athletics: subcommittee on the implications of academic values and standards (2006, May). Commercialism in college athletics. (Commercialism White Paper). Retrieved from http://webcache.googleusercontent.com/custom? $\mathrm{q}=$ cache:Xz7EhBs51RYJ: www.ncaa.org/wps/wcm/connect/.

Pocock, J. G. A. (1975). The Machiavellian moment. Princeton, NJ: Princeton University Press.

Rasmussen, D. B., \& Den Uyl, D. J. (1991). Liberty and nature: an Aristotelian defense of liberal order. LaSalle, IL: Open Court Publishing Company.

Roberts, J. (2008). A sane island surrounded. The Education Digest, 73(8), 61-66. Retrieved from Academic Search Complete database.

Shaw, D. (2000). How much is a student's attention worth? Curriculum Administrator, 36(4), 36-39.

Shuker, R. (2003). Part I social and cultural dimensions: 3. social phenomena: commercialism/commercialization. Continuum Encyclopedia of Popular Music of the World, 1, 179-183. Retrieved from Academic Search Complete database.

Sweat, N. S. (2007). Whiskey Speech (1952), The Southern Quarterly, 44(2), 112-113. Speech delivered to Mississippi Legislature, April 4, 1952. Retrieved from Academic Search Complete.

Twitchell, J. (1999). Lead Us Into Temptation. New York: Columbia University Press.

Zimbalist, A. S. (2006). The bottom line: observations and arguments on the sport business. Philadelphia, PA: Temple University Press.

Zimbalist, A. (1999). Unpaid professionals: Commercialism and conflict in big-time college sports. Princeton, NJ: Princeton University Press.

\section{AUTHOR'S ADDRESS:}

Robert C. Schneider

Department of Kinesiology, Sport Studies and Physical Education

State University of New York

350 New Campus Drive

Brockport, New York 14420, USA

Email: rschneid@brockport.edu 